\title{
Ceza Soruşturması ve Yaptırımlarının Caydırıcılık Etkisinin Değerlendirilmesi
}

\section{Evaluating the Deterrence Effect of Criminal Proceedings and Sanctions}

\author{
Nurcan Hamzaoğlu, Burcu Türk*, Yasemin Sanal
}

\begin{abstract}
Öz
Amaç: Toplum düzenini bozan davranışların suç olarak tanımlanması ve bu suçlara karşılık gelen cezalar sosyal bilimler açısından ilgi çekicidir. Suçlar için öngörülen cezalardan beklenen en önemli etkilerden bir tanesi de caydırıcılıktır. Mevcut çalışmada katılımcıların cezaların caydırıcılıklarına, soruşturma ve kovuşturma süreçlerine ilişkin algı ve tutumlarının değerlendirilmesi amaçlanmıştır.

Gereç ve Yöntem: Çalışma, araştırmacılar tarafından oluşturulan anket çalışmasının çevrimiçi uygulanması yolu ile, yaş aralığı 18-64 olan (yaş ortalaması 33,0土9,3) toplam 912 kişi ile gerçekleştirilmiştir.

Bulgular: Çalışma neticesinde katılımcılar tarafından yakalanma olasılığının en yüksek olduğu düşünülen suç tipi insan öldürmedir $(\% 63,8)$. Bir suçun ortaya çıkarılamamasında ise soruşturmanın etkin yapılmamasının etkili olduğunu belirten katılımcıların oranı $\% 69$ 'dur. Katılımcıların \%25,1'i işlenen suçlara verilen cezalarının caydırıcılık açısından yeterli olduğunu düşünürken; etkin pişmanlığa bağlı cezalandırmada indirim yapılmasının caydırıcılık etkisini azalttığını düşünen katılımcıların oranı \%67,4 ve iyi hal indiriminin suç işlemedeki caydırıcılık etkisini azalttı̆̆ını düşünen katılımcıların oranı ise \%70,8'dir. Katılımcıların \%13,4'ü “yakalanmayacağımı bilseydim bir suç işlerdim” derken bir kişinin işlediği suçtan dolayı yakalanma olasılığının yüksek olduğunu düşünen katılımcıların oran1 \%55,9'dur.

Sonuç: Çalışmadan elde edilen veriler doğrultusunda suç oranlarının azaltılması veya suçun engellenmesi için suç işleyen kişinin hiçbir şekilde verilecek cezadan kaçamayacağı, kısa sürede cezalandırılacağı ve verilen cezaların suç ile orantılı olduğu algısının geliştirilmesi gerektiği düşünülmektedir.

Anahtar kelimeler: Suç ve Ceza, Caydırıcılık, Tutum; Algı, Adli Bilimler
\end{abstract}

\section{Abstract}

Objective: Defining the behaviors that disrupt the social order as a crime and the penalties corresponding to these crimes have always been attractive in terms of social sciences. One of the most important effects expected from the penalties for crimes is deterrence. The present study aimed to evaluate the perceptions and attitudes of the participants regarding the deterrence of penalties, investigation and prosecution processes.

Materials and Methods: The study was carried out with a total of 912 people with an age range of 18-64 years (mean age 33,0 $\pm 9,3$ ) via online application of the survey created by the researchers.

Results: As a result of the study, the type of crime, which is considered by the participants as having the most probability of being seized, is the commitment of murder $(63,8 \%)$. The ratio of the participants who stated that the inefficiency in making an investigation is influential in not detecting crime is $69 \%$. While $25,1 \%$ of the participants think that criminal punishments are efficient for deterrence; $67.4 \%$ of respondents think that the reduction in effective punishment due to regret reduces the deterrence effect. $70,8 \%$ of the participants, on the other hands, think that good conduct time decreases the effectiveness of deterrence in committing a crime. While $13,4 \%$ of the participants say that "they would commit a crime if they knew they wouldn't get caught", 55,9\% of the participants who believe that the possibility of being seized because of committing a crime is high.

Conclusion: In accordance with the data obtained from the study; it is thought that the perceptions about the offender "cannot escape the punishment to be given in any way", "will be punished in a short time" and "the penalties are commensurate with the crime" should be improved in order to reduce the crime rate or to prevent the crimes.

Keywords: Crime and Punishment, Deterrence, Attitude; Perception, Forensic Sciences
DOI: 10.17986/blm.2019252288

Nurcan Hamzaoğlu: Dr. Öğr. Üyesi, İstanbul Yeni Yüzyıl Üniversitesi, Sağlık Bilimleri Enstitüsü, İstanbul Eposta: nurcan.hamzaoglu@yeniyuzyil. edu.tr ORCID iD: https://orcid.org/0000-00028471-0442

Burcu Türk: Dr. Öğr. Üyesi, Haliç Üniversitesi, Psikoloji Bölümü, İstanbul Eposta: burcuturk@halic.edu.tr ORCID iD: https://orcid.org/0000-00033290-5886

Yasemin Sanal: Dr. Öğr. Üyesi, Manisa Celal Bayar Üniversitesi, Psikoloji Bölümü, Manisa

Eposta: yasemin.sanal@cbu.edu.tr ORCID iD: https://orcid.org/0000-00023147-6269

\section{Bildirimler/ Acknowledgement}

Yazarlar bu makale ile ilgili herhangi bir çıkar çatışması bildirmemişlerdir. The authors declare that they have no conflict of interests regarding content of this article.

\section{Finansal Destek/Support Resources}

Yazarlar bu makale ile ilgili herhangi bir finansal destek bildirmemişlerdir.

The Authors report no financial support regarding content of this article.

*Sorumlu Yazar/Corresponding Author:

Geliş: 04.03.2019

Düzeltme: 29.04.2019

Kabul: 07.05.2019

p-ISSN: $1300-865 \mathrm{X}$

e-ISSN: $2149-4533$ 


\section{Giriş ve Amaç}

Suç ve suç ile mücadele konularına sosyal bilimler açısından bakıldığında, ceza ve diğer yaptırımlara ilişkin çalışmaların göze çarpan başlıklar olduğu görülmektedir. Ceza ve diğer yaptırımlarının suç işleme üzerindeki etkilerinin değerlendirilmesi ise, ilgili alanda çalışan araştırmacıların önemsediği temel konular arasında ön plana çıkmaktadır.

Geçmişten günümüze Dünya yazınında ilgili alanlarda birçok çalışma yapılmış ve halen yapılmaktadır. Suç, ceza ve toplumsal alg1 gibi kavramların dinamik kavramlar olması sebebiyle hem kavram içeriklerinin hem de yarattıkları etkilerin çeşitli faktörlere bağlı olarak dönemden döneme ve coğrafyadan coğrafyaya değişmesi karşılaşılan bir durumdur. İşbu değişim araştırmacılar için bu konuları ilgi odağı haline getirmektedir. Bu doğrultuda yabancı literatürde konuya ilişkin güncel çalışmalar yaygın olsa da ülkemizdeki toplumsal algı çalı̧̧malarının yetersiz kaldığı düşünülmektedir. Literatür incelendiğinde Türkiye'de caydırıcılık ile ilgili çalışmaların ağırlıklı olarak vergi kaçakçılığ 1 ve trafik cezalarına yoğunlaştığ göze çarpmaktadır; diğer suç tiplerine ilişkin incelemelerin ise yetersiz olduğu görülmektedir.

Mevcut çalışma açısından öncelikli olarak çeşitli kavramlara değinilmesi önem taşımaktadır. Türk Dil Kurumu'na (2006) göre ceza kelimesi, uygunsuz davranışlarda bulunanlara uygulanan üzüntü, sıkıntı, acı verici işlem veya yaptırım anlamına gelmekle birlikte; hukuki açıdan, suç işleyen bir kimsenin yaşantısına, özgürlügüüne, mallarına ve onuruna karşı yasaların öngördüğ̈̈ yaptırım anlamını taşımaktadır (1). Reynolds (1975) cezayı, istenmeyen davranışı takiben, davranışı yapan kişiye uygulanan onun hoşuna gitmeyecek bir işlem olarak tanımlar $(2,3)$. Diğer bir deyişle ceza, istenmeyen davranışın ortadan kaldırılması için yapılan müdahaleyi temsil etmektedir. Bu noktada bahsettiğimiz suç davranışı ise otoriteler tarafından kanun kapsamında tanımlanmış suç olarak nitelendirilen eylemlerdir. İnsan öldürme, yaralama, madde kullanımı, hırsılık, cinsel saldırılar, aile içi şiddet toplumlarda yaygın olarak karşılaşılan ve karşıl1ğında hukuki yaptırımlar bulunan suçlardan bazılarıdır. Suç yasanın belirlemiş olduğu eylemdir ve davranışın suç olarak tanımlanması görevi yine yasanın işidir (4).

Suçlar ve cezalar sıklıkla ortaya çıktıkları bağlam kapsamında değerlendirilirler. Suçlara karşılık kanun çerçevesinde ceza uygulamaları Babillerin 'göze göz' anlayışını temel alan Hammurabi Kanunlarından günümüz hukuk devletlerinin modern anlayışına kadar geniş bir yelpazede incelenebilir. Tarihsel boyuta bakıldığında azap çektirme, işkence, teşhir, sürgün gibi cezalar verilirken (5), günümüzde insan hak ve onurunun daha ön plan- da tutulabildiği cezalar kullanılmaktadır. Cezalandırma yöntemleri kitaplara konu olmuş, temel olarak da hapis, bedensel cezalar, idam ve günümüzde kullanımı sıklıkla yasadışı kabul edilen işkenceye odaklanılmıştır (6). Farklı dönemlerde, farklı coğrafyalarda, farklı uygulamalar gerçekleştirilmiş olmakla birlikte, her birinde suçlara karş1lı ortaya konan cezalar suçla mücadeledeki temel unsurların başında gelmiştir.

Bir suçun cezalandırılmasının altında yatan dört temel sebep öne sürülmektedir: (a) toplumun suçtan korunması ihtiyac1, (b) suçlunun 1slah edilmesi, (c) potansiyel suçlular için cezalandırmanın caydırıcılık görevini yerine getirmesi, (d) intikam almak (7). Cezaların işlevleri ve suçun sebeplerine yönelik özellikle yabancı literatürde birçok çalışma bulunmaktadır. Kompleks yapıya sahip olan suç kavramı farklı bakış açıları, değişkenler ve fark11 teoriler üzerinden çok zengin bir tartışma alanı ortaya koymaktadır. Mevcut çalışma yukarıda bahsi geçen özet niteliğindeki 4 temel sebepten caydırıcılık konusuna yoğunlaşmaktadır.

Beccaria, cezaların caydırıcılığını detaylı olarak tartıştı̆̆ 'Suçlar ve Cezalar Hakkında' eserinde (1764), cezanın biricik amacının benzer suçları işlemek isteyen başka insanları korkutarak suçtan caydırma olduğuna değinmiştir (8). Beccaria'ya göre caydırıcılığın gerçekleşmesi için verilecek cezanın kesinlik, hızlılık ve şiddetlilik unsurlarını içermesi gerekir. Cezaların kesinliği, verilecek cezanın açık ve net bir şekilde tanımlanmış olması ve suç işleyen kişinin de mutlaka bu cezayı çekeceği fikrine sahip olması olarak tanımlanmıştır. Cezaların hızlılı̆̆ , suç işleyen kişinin cezayı çekmeye başlama süreci ne kadar hızlı olursa etkisinin de o kadar artacağı şeklinde tanımlanmaktadır. Cezanın şiddetliliği ise, işlenen suç ve verilen cezanın arasında bir denge olmasıdır. Yanı işlenen suç karşıllı̆ında verilen ceza ne çok ağır ne de çok hafif olmalıdır. Teoride cezaların artması cezadan kaçınma amacı ile davranışın azalması ya da diğer bir deyişle uyum davranışının artması anlamına gelecektir. Cezalar eyleme karşılık olmalıdır ve suçtan vazgeçilmesini sağlamalıdır (4). Ceza adı altında, kanunlar kapsamında ortaya konan müdahaleler, suçluyu cezalandırmanın yanı sıra toplumda örnek teşkil ederek, başkaları tarafından aynı davranışın tekrarını önlemeyi yani caydırmayı da amaçlamaktadırlar. Böylece potansiyel suçluyu engelleyerek, suç önleme ad1na da işlevsellik kazanmaktadır. Barnes ve Teeters (1952) bir çalışmalarında, medeni toplumlarda halkın önünde verilen cezalardan vazgeçilmemesinin sebebini, cezalandırılan kişinin herkesin ders alacağı bir örnek olması inancına bağladığına değinmişlerdir (9). Ancak uygulamalara ve hukuk felsefesi kapsamında çalışmalara bakıldığında, cezaların diğer insanlara örnek olması işlevinin arzuland1- 
$\breve{g} 1$ şekilde yerine getirip getiremediği konusunda literatürde karşıt görüşler mevcuttur. Örnek olarak Livingston'un (1996) cezaların ve cezalandırma biçimlerinin ağır olmasının caydırıcılığı desteklediği ve aynı zamanda ağır ceza alan mahkumların tekrar ceza alma oranlarının düşük olduğu yönünde görüşleri mevcutken $(4,10)$; farklı ülkelerdeki çeşitli ceza uygulamalarının suç oranlarını düşürdügü görülmekte ise de bu ülkelerde ceza harici toplumsal faktörlerin daha ön planda olduğu ve cezalandırmanın caydırıcılık açısından direkt ve başarılı faktör olmadığını öne süren incelemeler (6) de yapılmıştır.

Farklı bir açıdan sosyal teorilere baktı̆̆ımızda, ödül ve ceza kavramlarını da içinde gördüğümüz, sosyal normlara uyma ve toplumun disiplini açısından da önem taşıyan taklit kavramını temel alan Albert Bandura'nın Sosyal Öğrenme Teorisi dikkat çekmektedir. Teoriye göre, bireylerin tepkileri diğerlerinin davranışlarının gözlemlenmesi sonucu ortaya çıkabilir; yani saldırganlık saldırgan modellerin taklidine bağlı gerçekleşebilir (11, 12). Bu noktada toplumun birbirini ya da medyayı takip ederek bir suçun cezalandırılması (ya da cezalandırılmaması), suçlunun yakalanması (ya da yakalanamaması), adalet beklentisi, sosyal normlar, ahlaki kaygilar, hukuk sistemine güven ve kolluk kuvvetlerine duyulan güven, suçtan uzak durma ya da suça karışma gibi açılardan çeşitli tutumlar ve bu doğrultuda davranışlar geliştirdiklerini de söylemek mümkündür.

Dolayısıyla suç ile ilişkilendirilen cezadan bahsettiğimizde, yukarıda da belirtildiği gibi yalnızca suçu gerçekleştiren birey için değil, davranışı gerçekleştirmeyi aklından geçiren bireyler için de ayrı anlam ve önem taşıyan bir kavramdan bahsettiğimiz unutulmamalıdır. Bu noktada ise bir diğer önemli detay ön plana çıkmaktadır: Potansiyel 'suçlu' ya da toplumdaki diğer bireylerin cezaların ne olduğunu bilip bilmemesi. Bir suça verilen cezanın caydırıcı olup olmaması, caydırıcılık etkisini yaşaması beklenen bireyin bilgi düzeyi ile de ilişkili olmalıdır. Kişi cezayı bilmelidir ki, cezadan kaçınsın. Oysa Apel (2012) çalışmasında, insanların cezaların olasılığını ve büyüklüğünü tahmin etmede oldukça zayıf bir iş yaptığını; ancak görece yaygın suçlar (alkol kullanımına ilişkin suçlar gibi) söz konusu olduğunda daha başarılı tahminlerde bulundukları sonucuna erişmiştir (13). Bunun yanı sıra insan öldürme ve yaralama gibi bazı suçların öfke ve kızgınlık anında işlenmesi bireyin her zaman ceza olgusu veya miktarını hesaba katmasına engel olabileceği düşüncesi de literatürde mevcuttur (14). Dolayısı ile caydır1c1lığın etkili olabilmesi bireylerin bir suça karşılık gelen cezayı bilmelerinin yanı sıra, suçlarının olası sonuçları ve cezayı değerlendirmek adına, çeşitli suçları gerçekleştirmeden önce zamana ihtiyaçları vardır.
Kolluk kuvvetlerinin etkinliğine dair tutumlar, suçlunun yakalanacağı ve suçun cezasız kalmayacağı inanc1, bir suça denk gelen cezanın uygulanması gibi faktörler suç davranışının ortaya çıkması açısından önem taşımaktadır. Cezaların eninde sonunda uygulanacağı ve cezadan kaçış olmadığı gerçeği bireyleri suçu işlemekten alıkoymaktadır. Cezadan kaçış ihtimalinin çok zayıf olması hatta mümkün olmaması asıl caydırıcıllğı sağlayacak faktör olarak görülmektedir (15). Toplumun huzur ve güvenliğini sağlamak için oluşturulan, aynı zamanda cezaların uygulanması açısından da ilk adımı oluşturan güvenlik kurumlarının etkinliklerine dair tutumlar yukarıda belirtildiği gibi cezaların caydırıcılıkları açısından önem taşıyan değişkenlerden birini oluşturmaktadır. Bu doğrultuda polisleri ele alacak olursak, görevlerini 2559 Sayılı Polis Vazife ve Salahiyet Kanunu çerçevesinde gerçekleştirdikleri görülmektedir. İlgili kanun kapsamında polislerin gerçekleştireceği önleyici, caydırıcı, düzenleyici ve koruyucu kolluk hizmetleri kapsamında gerçekleştirecekleri eylemler detayları ile aktarılmıştır (16). Toplumdaki bireylerin, polislerin görevlerini yerine getirmeleri üzerine gerçekleştirdikleri gözlemlerin, sosyal/informal öğrenme açısından, suça ve cezaya karşı davranışlarına yansıdığı düşünülmektedir.

Suçlunun yakalanmasına ilişkin görüşlerden bir diğeri de suçun işlenmesini takip eden süreç açısından önem taşıyan kamera, görüntü, kayıt sistemleridir. Türkiye'de yaygın olarak kullanılmakta olan MOBESE'lerin (Mobil Elektronik Sistem Entegrasyonu) bireylerin suç işleme davranışı konusunda caydırıcı etkisi olup olmaması çalışma açısından dikkat çekici bulunmuştur. 2000'li yılların başları itibariye öncelikle olarak farklı illerde pilot uygulamaları gerçekleştirilen MOBESE'ler 2008 y1lı itibari ile Türkiye'de tüm illerde aktif olarak kullanılmaya başlanmıştır (17). CCTV (Kapalı Devre Televizyon-closed circuit television) kameraların mekanizmasının altında yatan caydırıcılık sisteminin MOBESE'ler içinde geçerli olduğu düşünülmektedir. CCTV kameralar potansiyel suçlunun olay yerini kayıt altına alan kamerayı göz önünde bulundurarak suç işleyip işlememeyi değerlendirdiği vurgusunu yapmaktadır (18). Dolayısı ile bu sistemler sadece suçun belirlenmesi aşamasında değil, 7-24 izleniyor olmanın yaratacağı caydırıcılık üzerinden de çalışmakta ve bireylerin hem suç işleme davranışı üzerinde hem de suçlunun yakalanıp yakalanamayacağı inancı üzerinde etki sahibidir.

Mevcut çalışma sosyal ve betimleyici bir çalışma olup, genel olarak katılımciların, cezaların caydırıcilıklarına ve sürecin uygulanmasına ilişkin algı ve tutumlarını değerlendirmeyi amaçlamıştır. Bu değerlendirmeye ek olarak suçla mücadele kapsamında; bireylerin algısı boyutunda farklı suçlara dair cezaların pratikte kişileri 
suç işlemekten hangi boyutta uzak tuttuğu konusuna da odaklanılmıştır.

\section{Gereç ve Yöntem}

Ceza soruşturması ve yaptırımlarının suç işlemedeki caydırıcılık etkisinin değerlendirilmesi amacıyla gerçekleștirilen bu araştırmada tarama modeli kullanılmıştır. Tarama modelleri, geçmişte ya da halen var olan durumu var olduğu sekliyle betimlemeyi amaçlayan araştırma yaklaşımlarıdır. Araştırmaya konu olan olay, birey ya da nesne, kendi koşulları içinde ve olduğu gibi tanımlanmaya çalışılır (19).

Araştırmada katılımcıların demografik özelliklerini belirlemek ve ceza soruşturması ve yaptırımlarının suç işlemedeki caydırıcılık etkisinin değerlendirilmesi amacıyla araştırmacılar tarafından geliştirilen anket kullanılmıştır. 30 sorudan oluşan anketin ilk bölümünde katılımcıların tanımlayıcı özelliklerini (yaş, cinsiyet, medeni durum vs.) belirlemeye yönelik 7 soru, ikinci bölümünde ise katılımcıların cezaların caydırıcılığına ilişkin görüşlerine yönelik, ilgili literatürden elde edilen bilgilerden yararlanılarak oluşturulan, seçenekleri "tamamen katılıyorum"dan "hiç katılmıyorum"a doğru giden beşli Likert tipi niteliğinde toplam 23 soru yer almaktadır.

Çalışma için İstanbul Yeni Yüzyıl Üniversitesi Etik Kurulu'nun 04.07.2017 ve 2017/5 sayılı onay1 alındıktan sonra elektronik ortama aktarılan anket sosyal medya aracılığı ile kişilere ulaştırılmıştır. Eksiksiz olarak cevaplanan anketler araştırmaya dahil edilmiştir. Araştırmanın örneklemini, gönüllü olarak çalışmaya katılmayı kabul eden 912 kişi oluşturmuştur. Araştırma verileri, 10.07.2017- 15-10.2017 tarihleri arasında toplanmıştır.

Verilerin değerlendirilmesi SPSS 18 istatistik progra$\mathrm{m} ı$ ile yapılmıştır. İstatistiksel yöntem olarak tanımlayıcı istatistikler ve Ki-kare testi kullanılmıştır. Frekans dağılı$\mathrm{m} 1$ yüzde olarak sunulmuş, istatistiksel anlamlılık değeri $\mathrm{p}<0,05$ olarak kabul edilmiştir.

\section{Bulgular}

Katılımcıların yaş aralığı 18-64 olup, yaş ortalaması 33,0 99,3 olarak tespit edilmiştir. \%71,9'u erkek, 28,1'i kadın olan katılımcıların \%75,2'sinin öğrenim durumu lisans ve lisansüstüdür (Tablo 1).

Katılımcıların ceza soruşturması ve yaptırımlarının suç işlemedeki caydırıcılık etkisinin değerlendirilmesine yönelik anket sorularına cevaplarının dağılımı incelenirken "kesinlikle katılıyorum" ile "katılıyorum", "kesinlikle katılmıyorum" ile "katılmıyorum" cevaplarının frekansları birlikte değerlendirilmiştir.

Katılımcılar tarafından yakalanma olasılığının en yüksek olduğu düşünülen suç tipi insan öldürmedir ( $\% 63,8$;
Tablo 1. Katılımcıların demografik özellikleri $(\mathrm{n}=912)$

\begin{tabular}{|c|c|c|c|}
\hline & & $\mathbf{n}$ & $\%$ \\
\hline \multirow[t]{2}{*}{ Yaş (Ortalama $\pm \mathrm{ss})(\mathrm{y}$ 1l) } & Kadın & & $32,9 \pm 8,8$ \\
\hline & Erkek & & $33,0 \pm 9,5$ \\
\hline \multirow[t]{2}{*}{ Cinsiyet (\%) } & Kadın & 256 & 28,1 \\
\hline & Erkek & 656 & 71,9 \\
\hline \multirow[t]{2}{*}{ Medeni durum (\%) } & Bekar & 437 & 48,0 \\
\hline & Evli & 473 & 52,0 \\
\hline \multirow[t]{3}{*}{ Öğrenim durumu (\%) } & Lise ve daha az & 225 & 24,8 \\
\hline & Lisans & 523 & 57,7 \\
\hline & Yüksek lisans & 159 & 17,5 \\
\hline
\end{tabular}

n:582). İnsan öldürmeyi sırasıyla; yaralama suçları, cinsel suçlar, aile içi şiddet suçları, madde kullanım suçlar1 ve hırsızlık suçları takip etmektedir (\%34,5 (n: 315 ); \%33,8 (n:308); \%14,5’tir (n:132); \%12,1 (n:110); \%10,6 (n:97)). Katılımcıların suçlara ilişkin yakalanma olasılığı ile ilgili görüşleri cinsiyete göre değerlendirildiğinde; insan öldürme, yaralama, cinsel şiddet ve aile içi şiddet suçlarında yakalanma olasıllığının yüksek olduğunu düşünen erkeklerin oranı kadınlara göre istatistiksel olarak anlamlı derecede yüksek bulunmuştur. $(\mathrm{p}<0,05)$ (Tablo 2$)$.

Tablo 2. Cinsiyete göre suç tiplerine ilişkin yakalanma olasılığının yüksek olduğunu düşünen katılımcıların oranı

\begin{tabular}{|l|l|l|l|l|l|}
\hline & \multicolumn{2}{|c|}{ Kadın } & \multicolumn{2}{c|}{ Erkek } & \\
\hline & $\mathrm{n}$ & $\%$ & $\mathrm{n}$ & $\%$ & $\mathrm{p}^{*}$ \\
\hline İnsan Öldürme & 132 & 51,6 & $\mathbf{4 5 0}$ & $\mathbf{6 8 , 6}$ & $\mathbf{0 , 0 0 0}$ \\
\hline Yaralama suçları & 71 & 27,7 & $\mathbf{2 4 4}$ & $\mathbf{3 7 , 2}$ & $\mathbf{0 , 0 0 8}$ \\
\hline Madde kullanımı & 31 & 12,1 & 79 & 12,0 & 0,497 \\
\hline Hırsızlık & 30 & 11,7 & 67 & 10,2 & 0,686 \\
\hline Cinsel şiddet & 60 & 23,4 & $\mathbf{2 4 8}$ & $\mathbf{3 7 , 8}$ & $\mathbf{0 , 0 0 0}$ \\
\hline Aile içi şiddet & 256 & 10,5 & $\mathbf{6 5 6}$ & $\mathbf{1 6 , 0}$ & $\mathbf{0 , 0 4 9}$ \\
\hline
\end{tabular}

*Ki-Kare Analizi

Suçlara ilişkin yakalanma olasılığı eğitim durumuna göre değerlendirildiğinde ise; insan öldürme, yaralama suçları, madde kullanım suçları, hırsızlık suçları ve aile içi şiddet suçlarında gruplar arasında istatistiksel olarak anlamlı bir farklılık tespit edilmezken, sadece cinsel saldırı suçunda yakalanma olasılı̆̆ının yüksek olduğunu düşünen lisans üstü eğitim düzeyindeki katılımcıların oranı lisans veya daha az eğitim düzeyindeki katılımc1lara göre istatistiksel olarak anlamlı derecede yüksek bulunmuştur $(\mathrm{p}<0,05)$ (Tablo 3 ). 
Tablo 3. Öğrenim durumuna göre suç tiplerine ilişkin yakalanma olasılığının yüksek olduğunu düşünenlerin oranı

\begin{tabular}{|c|c|c|c|c|c|c|c|}
\hline & \multicolumn{2}{|c|}{ Lise ve daha az } & \multicolumn{2}{|c|}{ Lisans } & \multicolumn{2}{|c|}{ Yüksek lisans } & \multirow[b]{2}{*}{$\mathrm{p}^{*}$} \\
\hline & $\mathrm{n}$ & $\%$ & $\mathrm{n}$ & $\%$ & $\mathrm{n}$ & $\%$ & \\
\hline İnsan Öldürme & 135 & 60,0 & 337 & 64,4 & 106 & 66,7 & 0,208 \\
\hline Yaralama suçları & 72 & 32,0 & 186 & 35,6 & 55 & 34,6 & 0,692 \\
\hline Madde kullanımı & 35 & 15,6 & 59 & 11,3 & 16 & 10,1 & 0,247 \\
\hline Hirsızlik & 30 & 13,3 & 56 & 10,7 & 11 & 6,9 & 0,156 \\
\hline Cinsel saldırı & 76 & 33,8 & 192 & 36,7 & 38 & 23,9 & 0,043 \\
\hline Aile içi şiddet & 33 & 14,7 & 83 & 15,9 & 16 & 10,1 & 0,104 \\
\hline
\end{tabular}

*Ki-Kare Analizi

Bir suçun ortaya çıkarılamamasında; katılımcıların $\% 69,0$ (n:629)'u soruşturmanın etkin yapılmamasının, $\% 68,3$ (n:623)'ü görgü tanıklarının kaçınmasının, \% 64,9 (n: 592)'u suç işleyen kişinin sosyal statüsünün, \% 61,7 (n:563)'si yeterli delil olmasına rağmen delillerin toplanması ve değerlendirilmesindeki yetersizliğin, \% 36,4 (n:332)'ü kolluk kuvvetlerinin donanım eksikliğinin ve $\% 34,2$ (n:312)'si yeterli delil olmamasının etkili olduğunu belirtmiştir.

Suçun ortaya çıkarılamamasında, görgü tanıklarının kaçınması ve yeterli delil olmasına rağmen delillerin toplanması ve değerlendirilmesindeki yetersizliğin etkili olduğunu düşünen erkeklerin oranı kadınlara göre istatistiksel olarak anlamlı derecede yüksek bulunmuştur $(\mathrm{p}<0,05)$ (Tablo 4).

Tablo 4. Cinsiyete göre suçların ortaya çıkarılamama nedenleri

\begin{tabular}{|c|c|c|c|c|c|}
\hline & \multicolumn{2}{|c|}{ Kadın } & \multicolumn{2}{|c|}{ Erkek } & \multirow[t]{2}{*}{$\mathrm{p}^{*}$} \\
\hline & $\mathrm{n}$ & $\%$ & $\mathrm{n}$ & $\%$ & \\
\hline $\begin{array}{l}\text { Soruşturmanın etkin } \\
\text { yapılmaması }\end{array}$ & 180 & 70,3 & 449 & 68,4 & 0,583 \\
\hline $\begin{array}{l}\text { Görgü tanıklarının } \\
\text { kaçınması }\end{array}$ & 190 & 74,2 & 433 & 66,0 & 0,016 \\
\hline Yeterli delil olmaması & 92 & 35,9 & 220 & 33,5 & 0,492 \\
\hline $\begin{array}{l}\text { Yeterli delil olmasına } \\
\text { rağmen delillerin } \\
\text { toplanması ve } \\
\text { değerlendirilmesindeki } \\
\text { yetersizlik }\end{array}$ & 182 & 71,1 & 381 & 58,1 & 0,000 \\
\hline $\begin{array}{l}\text { Suç işleyen kişinin sosyal } \\
\text { statüsü }\end{array}$ & 177 & 69,1 & 416 & 63,3 & 0,094 \\
\hline $\begin{array}{l}\text { Kolluk Kuvvetlerinin } \\
\text { donanım eksikliği }\end{array}$ & 98 & 38,3 & 234 & 35,7 & 0,461 \\
\hline
\end{tabular}

*Ki-Kare Analizi
Suçun ortaya çıkarılamama nedenleri eğitim durumuna göre değerlendirildiğinde ise; soruşturma etkin yapılmadığı için suçun ortaya çıkmadığını düşünen yüksek lisans düzeyinde eğitimi olan katılımcıların oranı lisans veya daha az eğitimi olan katılımcılara göre anlamlı derecede yüksek bulunmuştur ( $\mathrm{p}<0,05)$ (Tablo 5).

Tablo 5. Öğrenim durumuna göre suçların ortaya çıkarılamama nedenleri

\begin{tabular}{|l|c|c|c|c|c|c|c|}
\hline & \multicolumn{2}{|c|}{$\begin{array}{l}\text { Lise ve } \\
\text { daha az }\end{array}$} & \multicolumn{2}{|c|}{ Lisans } & \multicolumn{2}{c|}{$\begin{array}{c}\text { Yüksek } \\
\text { lisans }\end{array}$} & \\
\hline & $\mathrm{n}$ & $\%$ & $\mathrm{n}$ & $\%$ & $\mathrm{n}$ & $\%$ & $\mathrm{p} *$ \\
\hline $\begin{array}{l}\text { Soruşturmanın etkin } \\
\text { yapılmamas1 }\end{array}$ & 149 & 66,2 & 351 & 67,1 & $\mathbf{1 2 6}$ & $\mathbf{7 9 , 2}$ & $\mathbf{0 , 0 0 8}$ \\
\hline $\begin{array}{l}\text { Görgü tanıklarının } \\
\text { kaçınmas1 }\end{array}$ & 154 & 68,4 & 357 & 68,3 & & 68,6 & 0,997 \\
\hline Yeterli delil olmamas1 & 86 & 38,2 & 177 & 33,8 & 48 & 30,2 & 0,249 \\
\hline $\begin{array}{l}\text { Yeterli delil olmasına } \\
\text { rağmen delillerin } \\
\text { toplanmas1 ve } \\
\text { değerlendirilmesindeki } \\
\text { yetersizlik }\end{array}$ & 134 & 59,6 & 315 & 60,2 & 111 & 69,8 & 0,069 \\
\hline $\begin{array}{l}\text { Suç işleyen kişinin } \\
\text { sosyal statüsü }\end{array}$ & 149 & 66,2 & 342 & 65,4 & 98 & 61,6 & 0,615 \\
\hline $\begin{array}{l}\text { Kolluk kuvvetlerinin } \\
\text { donanım eksikliği }\end{array}$ & 73 & 32,4 & & 37,5 & 62 & 9,0 & 0,326 \\
\hline
\end{tabular}

*Ki-Kare Analizi

Katılımc1ların \%90,1'i (n:822) güvenlik ve MOBESE kameralarının suçların ortaya çıkarılmasında etkili olduğunu, \%69'u (n:631) da etik kaygılar göz ardı edilerek toplumdaki tüm bireylerin parmak izi ve DNA profillerinin kayıt altına alınması gerektiğini düşünmektedir (Tablo 6). 
Tablo 6. Güvenlik Uygulamalarına Yaklaşım (Katılma oranlar1)

\begin{tabular}{|l|c|c|}
\hline & $\mathrm{n}$ & $\%$ \\
\hline $\begin{array}{l}\text { Güvenlik ve MOBESE kameraları suçların } \\
\text { ortaya çıkarılmasında etkilidir. }\end{array}$ & 822 & 90,1 \\
\hline $\begin{array}{l}\text { Etik kaygılar göz ardı edilerek toplumdaki tüm } \\
\text { bireylerin parmak izi ve DNA profillerinin } \\
\text { kayıt altına alınması gerekir }\end{array}$ & 629 & 69,0 \\
\hline Polis isterse tüm suçları aydınlatabilir. & 631 & 69,2 \\
\hline
\end{tabular}

İşlenen suçlara verilen cezalarının caydırıcılık açısından yeterli olduğunu düşünen katılımcıların oranı \% 25,1 'dir. Ünlülerin herhangi bir suçtan dolayı yakalanmasının ve cezalandırılmasının o suç için caydırıcılık açısından etkili olduğunu düşünenlerin oranı ise \% 63,9'dur (Tablo 7 ).

Tablo 7. Caydırıcı etkisi olduğu düşünülen uygulamalar (Katılma oranları)

\begin{tabular}{|l|c|c|}
\hline & $\mathrm{n}$ & $\%$ \\
\hline $\begin{array}{l}\text { Suçlara verilen cezaların caydırıcı etkisi } \\
\text { olduğunu düşünüyorum. }\end{array}$ & 229 & 25,1 \\
\hline $\begin{array}{l}\text { İşlenen suçlara göre verilen hapis cezalarının } \\
\text { yeterli olduğunu düşünüyorum. }\end{array}$ & 120 & 13,2 \\
\hline $\begin{array}{l}\text { Denetimli serbestlik uygulamasının faydalı } \\
\text { olduğunu düşünüyorum. }\end{array}$ & 318 & 34,4 \\
\hline $\begin{array}{l}\text { Ünlülerin herhangi bir suçtan dolayı } \\
\text { yakalanması, cezalandırılması o suç için } \\
\text { caydırıcı etki oluşturur. }\end{array}$ & 583 & 63,9 \\
\hline
\end{tabular}

Hırsızlık faillerinin yakalanamamasının bu suç üzerindeki caydırıcılık etkisini azalttığını düşünen katılımcıların oranı \% 87,7 (n:800), Cinayetlerin faili meçhul kalmasının suç işlemedeki caydırıcılık etkisini azalttığını düşünen katılımcıların oranı \% 78,7 (n:718), kısmi ya da genel af uygulamasının suç işlemedeki caydırıcılık etkisini azalttığını düşünen katılımcıların oranı \% 70,2 (n:640), etkin pişmanlığa bağlı cezalandırmada indirim yapılmasının caydırıcılık etkisini azalttığını düşünen katılımcıların oranı \% 67,4 (n:615) ve iyi hal indiriminin suç işlemedeki caydırıcılık etkisini azalttığını düşünen katılımcıların oran1 \% 70,8'dir (n: 646).

Caydırıcılık etkisi ile ilgili sorular cinsiyete göre değerlendirildiğinde; hırsızlık suçu faillerinin yakalanamamasının bu suç üzerindeki caydırıcılık etkisini azalttığını düşünen erkek katılımcıların oranı kadın katılımcılara göre istatistiksel olarak anlamlı derecede yüksek bulunmuştur $(p<0,05)$. İyi hal indiriminin suç işlemedeki caydırıcılık etkisini azalttığını düşünen kadın katılımcıların oranı ise erkek katılımcılara göre istatistiksel olarak anlamlı derecede yüksek bulunmuştur $(\mathrm{p}<0,05)$ (Tablo 8).
Katılımcıların tanıdıkları, tanımadıkları veya yakın arkadaş ya da aileden birinin suç işlediğini öğrendikleri zaman verecekleri tepki sorulduğunda; tanımadığım birinin suç işlediğine şahit olsaydım polise ihbar ederdim diyen katılımcıların oranı \% 89,0 (n:812) iken tanıdığım birinin suç işlediğini öğrenseydim polise ihbar ederdim diyen katılımcıların oranı \% 70,7 (n:645), ailemden veya yakın arkadaşlarımdan birinin suç işlediğini öğrenseydim polise ihbar ederdim diyen katılımcıların oranı \% 53,3 e (n:486) düşmektedir. İhbara ilişkin sorular cinsiyete göre değerlendirildiğinde; tanıdığım birinin suç işlediğini görseydim ve tanımadığım birinin suç işlediğini görseydim polise ihbar ederdim diyen kadın ve erkek katılımcılar arasında istatistiksel olarak anlamlı bir farklılık tespit edilmezken aile üyelerinden veya yakın arkadaşlardan birinin suç işlediğinin öğrenilmesi durumunda polise ihbar edeceğini söyleyen kadın katılımcıların oranı erkek katılımcılara göre istatistiksel olarak anlamlı derecede yüksek bulunmuştur $(\mathrm{p}<0,05)$ Tablo 8$)$.

Yakalanmaktan korktuğu için şimdiye kadar hiç suç işlemediğini söyleyen katılımcıların oranı \% 32,7'dir (n:298). Yakalanmayacağımı bilseydim bir suç işlerdim diyen katılımcıların oranı ise \% 13,4'tür (n:122). Katılımcıların cevapları cinsiyete göre değerlendirildiğinde; yakalanmayacağımı bilseydim bir suç işlerdim diyen erkek katılımcıların oranı kadın katılımcılara göre istatistiksel olarak anlamlı derecede yüksek bulunmuştur $(\mathrm{p}<0,05)$ (Tablo 8).

Bir kişinin işlediği suçtan dolayı yakalanma olasıl1ğının yüksek olduğunu düşünen katılımcıların oranı \% 55,9 (n:510); Bir kişinin işlediği suç akabinde yakalanma süresinin kısa olduğunu düşünen katılımcıların oranı \% 20,3’tür (n:185). Bir kişinin işlediği suçtan dolayı adalet önüne çıkarılmasının 6 aydan uzun sürdüğünü düşünen katılımcıların oranı \% 53,9 (n:491), kişinin işlediği suçtan dolayı cezasının kesinleşmesinin bir yıldan uzun sürdüğünü düşünen katılımcıların oranı \% 73,2 (n:668)'dir. Tutukluluk sürelerinin uzun olduğunu düşünen katılımc1ların oranı ise \% 47'dir (n: 429).

Soruşturma ve kovuşturma evrelerinin sürelerine ilişkin sorular cinsiyete göre değerlendirildiğinde; bir kişinin işlediği bir suçtan dolayı adalet önüne çıkarılmasının 6 aydan uzun sürdüğünü belirten katılımcılar ve bir kişinin işlediği bir suçtan dolayı cezasının kesinleşmesinin 1 yıldan uzun sürdüğünü belirten katılımcılar arasında cinsiyete göre istatistiksel olarak anlamlı bir farklılık yokken, bir kişinin işlediği bir suçtan dolayı yakalanmasının kısa sürdügünü ve bir kişinin işlediği bir suçtan dolayı yakalanma olasılığının yüksek olduğunu düşünen erkek katılımcıların oranı kadın katılımcılara göre istatistiksel olarak anlamlı derecede yüksek bulunmuştur $(\mathrm{p}<0,05)$ (Tablo 8$)$. 
Tablo 8. Cinsiyete göre işlenen suçlara yaklaşım (Katılma oranları)

\begin{tabular}{|c|c|c|c|c|c|}
\hline & \multicolumn{2}{|c|}{ Kadın } & \multicolumn{2}{|c|}{ Erkek } & \multirow[b]{2}{*}{$\mathrm{p}$} \\
\hline & $\mathrm{n}$ & $\%$ & $\mathrm{n}$ & $\%$ & \\
\hline Güvenlik ve MOBESE kameraları suçların ortaya çıkarılmasında etkilidir. & 217 & 84,8 & 605 & 92,2 & $\mathbf{0 , 0 0 1}$ \\
\hline $\begin{array}{l}\text { Etik kaygılar gözardı edilerek toplumdaki tüm bireylerin parmak izi ve DNA } \\
\text { profillerinin kayıt altına alınması gerekir. }\end{array}$ & 169 & 66,0 & 460 & 70,1 & 0,228 \\
\hline Polis isterse tüm suçları aydınlatabilir. & 180 & 70,3 & 451 & 68,8 & 0,646 \\
\hline Tutukluluk sürelerinin uzun olduğunu düşünüyorum. & 14 & 23,3 & 84 & 45,2 & $\mathbf{0 , 0 0 3}$ \\
\hline Bir kişinin işlediği bir suçtan dolayı yakalanma olasılığg yüksektir. & 105 & 41,0 & 405 & 61,7 & $\mathbf{0 , 0 0 0}$ \\
\hline Bir kişinin işlediği bir suçtan dolayı yakalanması kısa sürer. & 39 & 15,2 & 146 & 22,3 & $\mathbf{0 , 0 1 7}$ \\
\hline Bir kişinin işlediği bir suçtan dolayı adalet önüne çıkarılması 6 aydan uzun sürer. & 150 & 58,6 & 342 & 52,1 & 0,079 \\
\hline Bir kişinin işlediği bir suçtan dolayı cezasının kesinleşmesi 1 yıldan uzun sürer. & 180 & 70,3 & 488 & 74,4 & 0,211 \\
\hline Tanımadığım birinin suç işlediğine şahit olsaydım polise ihbar ederdim. & 229 & 89,5 & 583 & 88,9 & 0,801 \\
\hline Tanıdığım birinin suç işlediğini öğrenseydim polise ihbar ederdim. & 192 & 75,0 & 453 & 69,1 & 0,076 \\
\hline $\begin{array}{l}\text { Ailemden veya yakın arkadaşlarımdan birinin suç işlediğini öğrenseydim polise ihbar } \\
\text { ederdim. }\end{array}$ & 152 & 59,4 & 334 & 50,9 & 0,021 \\
\hline $\begin{array}{l}\text { Hırsızlık faillerinin yakalanamaması bu suç üzerinde caydırıcılık etkisini azalttığını } \\
\text { düşünüyorum. }\end{array}$ & 211 & 82,4 & 589 & 89,8 & $\mathbf{0 , 0 0 2}$ \\
\hline $\begin{array}{l}\text { Cinayetlerin faili meçhul kalmasının suç işlemedeki caydırıcılık etkisini azalttığını } \\
\text { düşünüyorum. }\end{array}$ & 199 & 77,7 & 519 & 79,1 & 0,647 \\
\hline $\begin{array}{l}\text { Kısmi ya da genel af uygulamasının suç işlemedeki caydırıcılık etkisini azalttığını } \\
\text { düşünüyorum. }\end{array}$ & 188 & 73,4 & 452 & 68,9 & 0,179 \\
\hline İyi hal indiriminin suç işlemedeki caydırıcılık etkisini azalttığını düşünüyorum. & 195 & 76,2 & 451 & 68,8 & $\mathbf{0 , 0 2 7}$ \\
\hline $\begin{array}{l}\text { Etkin pişmanlığa bağlı cezalandırmada indirim yapılmasının caydırıcılık etkisini } \\
\text { azalttığını düşünüyorum. }\end{array}$ & 183 & 71,5 & 432 & 65,9 & 0,103 \\
\hline $\begin{array}{l}\text { Ünlülerin herhangi bir suçtan dolayı yakalanması, cezalandırılması o suç için caydırıcı } \\
\text { etki oluşturur. }\end{array}$ & 133 & 52,0 & 450 & 68,6 & $\mathbf{0 , 0 0 0}$ \\
\hline Denetimli serbestlik uygulamasının faydalı olduğunu düşünüyorum. & 70 & 27,3 & 248 & 37,8 & $\mathbf{0 , 0 0 1}$ \\
\hline Yakalanmaktan korktuğum için şimdiye kadar hiçbir suç işlemedim. & 78 & 30,5 & 220 & 33,5 & 0,375 \\
\hline Yakalanmayacağımı bilseydim bir suç işlerdim. & 24 & 9,4 & 98 & 14,9 & $\mathbf{0 , 0 2 7}$ \\
\hline Suçlara verilen cezaların caydırıcı etkisi olduğunu düşünüyorum. & 41 & 16,0 & 188 & 28,7 & $\mathbf{0 , 0 0 0}$ \\
\hline İşlenen suçlara göre verilen hapis cezalarının yeterli olduğunu düşünüyorum. & 29 & 11,3 & 91 & 13,9 & 0,307 \\
\hline
\end{tabular}

*Ki-Kare Analizi

Soruşturma ve kovuşturma evrelerinin sürelerine ilişkin sorular eğitim durumuna göre değerlendirildiğinde ise; sadece kişinin işlediği bir suçtan dolayı cezasının kesinleşmesinin bir y1ldan uzun sürdüğünü düşünen lisans ve yüksek lisans eğitim düzeyindeki katılımcıların oranı lise ve altı eğitime sahip katılımcılara göre anlamlı derecede yüksek bulunmuştur $(\mathrm{p}<0,05)$ (Tablo 9).

\section{Tartışma}

Caydırıcılık teorisi günümüzde suçun önlenmesi çalışmalarının temelini oluşturmaktadır. Ancak ülkemizde mevcut literatürde sosyal bilimler açısından cezaların caydırıcılığına ilişkin sınırlı sayıda çalışma bulunmaktadır. Cezaların caydırıcı etkisi; cezanın kesinliği, şiddeti ve hızlılığ 1 üzerinden değerlendirilmekle birlikte, yapılan çalışmalar cezanın kesinliğinin diğer değişkenlere göre caydırıcılık açısından daha etkili olduğunu göstermektedir. Birçok araştırmacı tarafından $(15,20,21)$ "cezaların kesinliği” ilkesi caydırıcılığın en önemli unsurlarından biri olarak kabul edilmektedir. İşlenen bir suçun mutlaka cezalandırılacağı algısı suçu önleme açısından caydırıcı bir etkiye sahiptir. Bu kapsamda, toplumun ceza soruşturması ve yaptırımların caydırıcılık etkisine ilişkin algısının değerlendirilmesini amaçladığımız bu çalışmada, cezaların kesinliği algısını etkileyen unsurlar tespiti üzerinde özellikle durulmuştur.

Mevcut çalışmada, "yakalanmaktan korktuğum için şimdiye kadar hiçbir suç işlemedim" diyen katılımcıların oranı $\% 32,7$, "bir kişinin işlediği suçtan dolayı yakalanma olasılığını yüksektir" diyen katılımcıların oranı da \%55,9 olup bu veriler cezaların kesinliğine ilişkin algının yüksek olmadığını gösteren bulgu olarak ele alınmıştır. 
Tablo 9. Öğrenim durumuna göre işlenen suçlara yaklaşım

\begin{tabular}{|c|c|c|c|c|c|c|c|}
\hline & \multicolumn{2}{|c|}{ Lise ve daha az } & \multicolumn{2}{|c|}{ Lisans } & \multicolumn{2}{|c|}{ Yüksek lisans } & \multirow[b]{2}{*}{$\mathrm{p}^{*}$} \\
\hline & $\mathrm{n}$ & $\%$ & $\mathrm{n}$ & $\%$ & $\mathrm{n}$ & $\%$ & \\
\hline $\begin{array}{l}\text { Güvenlik ve MOBESE kameraları suçların ortaya çıkarılmasında } \\
\text { etkilidir. }\end{array}$ & 201 & 89,3 & 482 & 92,2 & 135 & 84,9 & $\mathbf{0 , 0 2 3}$ \\
\hline $\begin{array}{l}\text { Etik kaygılar gözardı edilerek toplumdaki tüm bireylerin parmak izi ve } \\
\text { DNA profillerinin kayıt altına alınması gerekir. }\end{array}$ & 177 & 78,7 & 360 & 68,8 & 87 & 54,7 & $\mathbf{0 , 0 0 0}$ \\
\hline Polis isterse tüm suçları aydınlatabilir. & 162 & 72,0 & 346 & 66,2 & 119 & 74,8 & 0,065 \\
\hline Tutukluluk sürelerinin uzun olduğunu düşünüyorum. & 20 & 30,8 & 62 & 46,3 & 15 & 33,3 & 0,069 \\
\hline Bir kişinin işlediği bir suçtan dolayı yakalanma olasılığı yüksektir. & 123 & 54,7 & 306 & 58,5 & 79 & 49,7 & 0,131 \\
\hline Bir kişinin işlediği bir suçtan dolayı yakalanması kısa sürer. & 46 & 20,4 & 112 & 21,5 & 25 & 15,7 & 0,287 \\
\hline $\begin{array}{l}\text { Bir kişinin işlediği bir suçtan dolayı adalet önüne çıkarılması } 6 \text { aydan } \\
\text { uzun sürer. }\end{array}$ & 117 & 52,0 & 275 & 52,6 & 97 & 61,0 & 0,141 \\
\hline $\begin{array}{l}\text { Bir kişinin işlediği bir suçtan dolayı cezasının kesinleşmesi } 1 \text { yıldan } \\
\text { uzun sürer. }\end{array}$ & 148 & 65,8 & 390 & 74,6 & 128 & 80,5 & 0,004 \\
\hline $\begin{array}{l}\text { Tanımadığım birinin suç işlediğine şahit olsaydım polise ihbar } \\
\text { ederdim. }\end{array}$ & 200 & 88,9 & 471 & 90,1 & 136 & 85,5 & 0,280 \\
\hline Tanıdığım birinin suç işlediğini öğrenseydim polise ihbar ederdim. & 160 & 71,1 & 369 & 70,6 & 112 & 70,4 & 0,985 \\
\hline $\begin{array}{l}\text { Ailemden veya yakın arkadaşlarımdan birinin suç işlediğini } \\
\text { ögrenseydim polise ihbar ederdim. }\end{array}$ & 128 & 56,9 & 271 & 51,8 & 85 & 53,5 & 0,443 \\
\hline $\begin{array}{l}\text { Hırsılılı faillerinin yakalanamaması bu suç üzerinde caydırıcılık } \\
\text { etkisini azalttığını düşünüyorum. }\end{array}$ & 192 & 85,3 & 463 & 88,5 & 141 & 88,7 & 0,439 \\
\hline $\begin{array}{l}\text { Cinayetlerin faili meçhul kalmasının suç işlemedeki caydırıcılık } \\
\text { etkisini azalttığını düşünüyorum. }\end{array}$ & 171 & 76,0 & 418 & 79,9 & 125 & 78,6 & 0,485 \\
\hline $\begin{array}{l}\text { Kısmi ya da genel af uygulamasının suç işlemedeki caydırııılık } \\
\text { etkisini azalttı̆̆ını düşünüyorum. }\end{array}$ & 155 & 68,9 & 371 & 70,9 & 112 & 70,4 & 0,853 \\
\hline $\begin{array}{l}\text { İyi hal indiriminin suç işlemedeki caydırıcılık etkisini azalttığını } \\
\text { düşünüyorum. }\end{array}$ & 162 & 72,0 & 369 & 70,6 & 112 & 70,4 & 0,915 \\
\hline $\begin{array}{l}\text { Etkin pişmanlığa bağlı cezalandırmada indirim yapılmasının } \\
\text { caydıcılık etkisini azalttığını düşünüyorum. }\end{array}$ & 157 & 69,8 & 353 & 67,5 & 102 & 64,2 & 0,511 \\
\hline $\begin{array}{l}\text { Ünlülerin herhangi bir suçtan dolayı yakalanması, cezalandırılması o } \\
\text { suç için caydırıcı etki oluşturur. }\end{array}$ & 150 & 66,7 & 331 & 63,3 & 100 & 62,9 & 0,640 \\
\hline Denetimli serbestlik uygulamasının faydalı olduğunu düşünüyorum. & 77 & 34,2 & 180 & 34,4 & 60 & 37,7 & 0,718 \\
\hline Yakalanmaktan korktuğum için şimdiye kadar hiçbir suç işlemedim. & 77 & 34,2 & 165 & 31,5 & 54 & 34,0 & 0,717 \\
\hline Yakalanmayacağımı bilseydim bir suç işlerdim. & 40 & 17,8 & 66 & 12,6 & 16 & 10,1 & 0,064 \\
\hline Suçlara verilen cezaların caydırıcı etkisi olduğunu düşünüyorum. & 57 & 25,3 & 128 & 24,5 & 44 & 27,7 & 0,718 \\
\hline $\begin{array}{l}\text { İşlenen suçlara göre verilen hapis cezalarının yeterli olduğunu } \\
\text { düşünüyorum. }\end{array}$ & 32 & 14,2 & 68 & 13,0 & 20 & 12,6 & 0,871 \\
\hline
\end{tabular}

$\mathrm{Bu}$ oran, katılımcıların suçlara ilişkin yakalanma olasılı̆̆ 1 algılarının ve dolayısıyla cezaların kesinliği algılarının orta ve düşük düzeyde olduğu göstermektedir. Özcan ve ark. (2011) tarafından ceza algısının uyuşturucu kullanımı üzerindeki caydırıcılık etkisi ile ilgili yapılan çalışmada elde edilen sonuçlarda, cezaların kesinliğine ilişkin bu bulguyu destekler niteliktedir (22). Öğrenciler ile gerçekleştirilen söz konusu çalışmada uyuşturucu kullanımını azaltmada: okul idaresinin uyuşturucu kullanımını fark etme ihtimalinin; hapis cezası alma ihtimali, hapis ceza- sının miktarı, okul idaresinin vereceği cezanın miktarı ve süresinden daha etkili olduğu tespit edilmiştir. Dolayısıyla yakalanma ihtimali ile yakalanma sonucu ceza alma durumunun kişi üzerinde yarattığı etkilerin farklı olduğu söylenebilir. Türk ve Yavuz (2018) tarafindan yapılan bir araştırmada da üniversite öğrencilerinin madde kullanımı halinde gerek okul idaresinin gerekse kolluk kuvvetlerinin fark etmesi ve yakalama ihtimaline olan inanışlarının azımsanmayacak bir şekilde düşük oranlarda olduğu tespit edilmiştir (23). Chamblis (1966) tarafından yapılan 
bir araştırmada da park ihlallerine yönelik cezaların ağırlaştırılması ve daha etkin uygulanmaya başlanmasının ardından park ihlallerinin önemli ölçüde azaldığı tespit edilmiştir (24). Elde edilen veriler, suç işleyen kişinin yakalanacağı ve ceza alacağı algısının (ve dolayısıyla cezaların kesinliği algısının) yüksek olması ile kişinin cezalara bağlı suç işlemekten cayma davranışı arasındaki ilişkiyi belirgin olarak ortaya koymaktadır.

Mevcut çalışmada, diğer insanları ya da medyayı takip ederek bir suçun cezalandırılması (ya da cezalandırılmaması), suçlunun yakalanması (ya da yakalanamaması) sonucu ortaya çıkan toplumsal algının da cezaların kesinliği algısını etkilediği tespit edilmiştir. Nitekim ünlülerin herhangi bir suçtan dolayı yakalanması ve cezalandırılmasının o suç için caydırıcı etki oluşturduğunu düşünen katılımcıların oranı \%63,9'dur. Hırsızlık faillerinin yakalanamamasının suç üzerindeki caydırıcılık etkisini azalttığını düşünen katılımcıların oranı ise \%87,7'dir. Elde edilen bulgular Türk ve Yavuz'un (2018) çalışması ile paralellik göstermektedir (23). Söz konusu çalışmada da; toplumda tanınan kişilerin madde kullanımı nedeniyle yakalanmasının ve cezalandırılmasının caydırıcı bir etki oluşturduğunu düşünen katılımcıların oranı \% 49,1 olarak tespit edilmiştir.

Aile içi şiddet ve cinsel şiddet suçlarında yakalanma olasılığı tüm katılımcılar tarafından düşük veya orta düzeyde değerlendirilirken, cinsiyete göre baktığımızda bu suçlarda yakalanma olasılığının düşük olduğunu belirten kadın katılımcıların oranının erkek katılımcılara göre daha yüksek olduğu tespit edilmiştir. Bu farklılığın; şiddetin, kadınlar ve erkekler tarafindan algılanması, tanımlanması ve yorumlanmasındaki farklılıklardan kaynaklandığı düşünülmektedir. Dumrul ve Danacı'nın (2015) raporunda bu konuya ilişkin, cinsel özgürlüğe karşı işlenen suçlara özgü özel bir sicil ve infaz rejiminin bulunmaması, cezaların caydırıcılığını ortadan kaldırdığı gibi, mağdurda ve toplumda şeklen ceza alan failin dahi fiilen cezasız kalacağı yönünde yaygın bir kanı oluşmasına yol açmaktadır denmektedir (25). Mevcut çalışmadaki bulguların kaynağında da bunun olabileceği düşünülmektedir. Ayrıca iyi hal indiriminin suç işlemedeki caydırıcılık etkisini azalttığını düşünen kadın katılımcıların oranının erkek katılımcılara göre istatistiksel olarak anlamlı derecede yüksek bulunması da göz önüne alındığında bu sonuçların toplumsal cinsiyet algısı ile de ilişkili olabileceği düşünülmektedir.

Bir suçun ortaya çıkarılamamasında; katılımcıların \%69'u soruşturmanın etkin yapılmamasının, \%61,7'si delillerin toplanması ve değerlendirilmesindeki yetersizliğin etkili olduğunu belirtmiştir. Ayrıca katılımcıların \%74,9'u verilen cezaların caydırıcılık açısından yetersiz olduğunu, \%69,2'si ise polisin isterse tüm suçları aydınlatabileceğini belirtmiştir. $\mathrm{Bu}$ sonuçlar, katılımcıların "cezaların kesinliği” algısının düşük olduğunu desteklemekle birlikte, "cezaların şiddetliliği" algılarının da düşük olduğunu göstermektedir. Cezaların şiddetliliği ve kesinliği ilkeleri ile suç işleme arasında negatif ve anlam11 bir ilişki olduğu düşünüldüğünde toplumda bu ilkelere yönelik algıyı olumlu yönde artıracak uygulamaların suç oranlarını da azaltabileceği düşünülmektedir.

Caydırıcılık teorisinin temel ilkelerinden bir diğeri de “cezanın hızlılığı” ilkesidir. Buna göre suç işleyen kişinin cezalandırılmasının kısa sürede gerçekleşmesi, cezaların caydırıcı olabilmesi için gerekli unsurlardan biridir. Delice (2012) tarafından hız, alkol ve genel trafik denetimlerinin etkinliği ile ilgili yapılan bir çalışmada; cezaların sürücülere bildirilme süresinin uzunluğu, denetimlerin etkili olmamasının nedenlerinden biri olarak belirtilmiştir (26). Türkmen'in (2018) çalışmasında geçen "soruşturma ya da kovuşturma aşamalarının uzun sürmesi toplumda suçların cezasız kaldığı şeklinde bir algı oluşturmakta bu durum ise cezalardan beklenen en büyük faydalardan biri olan caydırıcılık özelliğinin kaybolmasına neden olmaktadır" ifadesini destekler niteliktedir (27). Mevcut çalışmada da, yakalanma ve cezanın kesinleşme süresine ilişkin katılımcıların algısına bakıldığında; bir kişinin işlediği suçtan dolayı yakalanma süresinin kısa olduğunu düşünen katılımcıların oranının \%20,3; kişinin işlediği suçtan dolayı cezasının kesinleşmesinin bir yıldan uzun sürdüğünü düşünen katılımcıların oranının $\% 73,2$ olduğu göz önüne alındığında katılımcıların cezanın hızlılığına dair görüşlerinin literatürle paralel olduğu görülmektedir.

Çalışmada elde ettiğimiz önemli bulgulardan bir diğeri de; suçların ortaya çıkarılması için güvenlik ve MOBESE kameralarının kullanımı ve etik kaygılar göz ardı edilerek tüm bireylerin parmak izi ve DNA profillerinin kayıt altına alınmasına ilişkin görüşleridir. Katılımcıların \%90'1 MOBESE ve güvenlik kameralarının suçların ortaya çıkarılmasında etkili olduğunu belirtirken \%69'u toplumdaki tüm bireylerin parmak izi ve DNA profillerinin kayıt altına alınması gerektiğini belirtmiştir. Bu doğrultuda elde edilen veri çalışmanın giriş bölümünde aktarılan beklentiler ile paralellik oluşturmaktadır.

\section{Sonuç ve Öneriler}

Suçun gerçekleşmesinin ardından ortaya çıkan zararın giderilmesindense, suç işlenmesinin önlenmesi yalnızca hukuki ve ekonomik olarak değil aynı zamanda suça dahil olan ve suçtan zarar gören bireylerin ruh ve beden sağlığının korunması açısından da daha yerindedir. $\mathrm{Bu}$ doğrultuda bireylerin suça yönelik tutumları, cezalara 
ilişkin algıları ve suçtan uzak durma adına attıkları adımlar büyük önem taşımaktadır.

Mevcut çalışma, bireylerin algı ve tutumlarını ortaya koyma ve ileride yapılacak çalışmalara katkı sağlama amacı taşımaktadır. Ancak çalışmaya katılan bireylerin \%71,9'u erkek, \%28,1'inin kadın olması cinsiyetler arası karşılaştırma imkanını zorlaştırmıştır. Konuyla ilgili yapılacak gelecek araştırmalarda kadın ve erkek katılımcılar arasında daha net karşılaştırmaların yapılabilmesi adına, daha fazla kadın katılımcıya ulaşılması yerinde olacaktır. Ayrıca bireylerin daha önce herhangi bir suça karışıp karışmadıkları ve bununla ilintili soruların sorulmasının yanı sıra bu konu kapsamında yapılacak çalışmalarda kişilik özellikleri, adil dünya inancı, toplumsal cinsiyet algıs1 gibi bireylerin tutumlarını etkileyebilecek nedenlerin de araştırılmasının faydalı olacağı düşünülmektedir. Suçla mücadelede ceza yaptırımlarının toplumsal açıdan etkilerinin belirlenmesi adına sosyal çalışmaların yaygınlaştırılması önem taşımaktadır.

Cezaların bireysel caydırıcılık rolünün yanı sıra bir diğer rolü de toplumsal caydırıcılık rolüdür. Bu noktada caydırıcılık teorisine göre; cezaların kesinliği, şiddetlili$\breve{g i}$ ve hızlılığı toplumsal caydırıcılık açısından önemlidir. Çalışmadan elde edilen veriler doğrultusunda suç oranlarının azaltılması veya suçun engellenmesi için suç işleyen kişinin hiçbir şekilde verilecek cezadan kaçamayacağ 1 algisı, kısa sürede cezalandırılacağı ve verilen cezaların suç ile orantılı olduğu algısının geliştirilmesi gerekmektedir. Bununla birlikte, suçluları yakalama görevini üstlenen kolluk kuvvetlerinin suç ve suçla mücadelede daha etkin hale getirilmesi gerektiği düşünülmektedir.

Elde edilen veriler ışığında, yalnızca caydırma amacı ile konan cezaların önleme açısından etkilerinin zayıf olabileceği; bunun yerine toplumun bilinçlendirilmesi, insan odakl1, gerçekçi, bütüncül ve adil uygulamalardan oluşan politikaların geliştirilmesinin önleme açısından etkili olacağı öngörülmektedir.

\section{Kaynaklar}

1. Türk Dil Kurumu (2006), Ceza. http://www.tdk.gov.tr/ index.php?option $=$ com_gts\& arama $=$ gts \& guid=TDK. GTS.5b8900bf9b99a2.30727599 (Erişim Tarihi: 15.08.2018).

2. Reynolds GS. A primer of operant conditioning. 2nd ed. Glenview, IL: Scott Foresman; 1975.

3. Aypay A. Ergen gözüyle ceza ve etkileri. Ahi Evran Üniversitesi Kırşehir Eğitim Fakültesi Dergisi (KEFAD). 2017;18(1):249-68.

4. Işıktaç Y. Ceza adaleti açısından hapis cezası ve rehabilitasyon ilişkisi. İstanbul Üniversitesi Hukuk Fakültesi Mecmuas1. 2013;71(1):625-38
5. Foucault M. Hapishanenin Doğuşu. 4. Basım. Çev. Mehmet Ali Kılıçbay, İmge Kitabevi, 2013;Ankara

6. Lyons L. Cezalandırmanın Tarihi. Çev. Silya Zengilli. Paris Yayınları, 2017; İstanbul.

7. Işıktaç Y. Adalet Psikolojisi. 1.Basım. İstanbul Bilgi Üniversitesi Yayınları, 2013; İstanbul.

8. Beccaria C. Suçlar ve Cezalar Hakkında. Çev: Sami SELÇUK, İmge Kitabevi, 2004;Ankara.

9. Barnes HE, Teeters NG. (1956). İlkel Cezalar ve Fiziksel Cezanın Başlıca Türleri. Çev: Aydın, Ankara Barosu Dergisi, 2011;(4)

10. Livingston J. Crime and Criminology. New Jersey, PrenticeHall Publications, 1996; p.504

11. Bilgin N. Sosyal psikolojiye giriş. 5.Basım. Ege Üniversitesi Edebiyat Fakültesi Yayınları, 2013;:̇zmir.

12. Bilgin N. Sosyal Psikoloji Sözlüğü. 3.Basım. Bağlam Yayınları, 2016; İstanbul.

13. Apel R. Sanctions, perceptions, and crime: Implications for criminal deterrence. Journal of quantitative criminology, 2013;29(1), 67-101. DOI: https://doi.org/10.1007/s10940012-9170-1

14. Kızmaz Z. Ceza veya Kriminal Yaptırımın Suç Oranlan1 Üzerindeki Caydırıcı Etkisi. Sosyal Bilimler Dergisi 2005;7(2), 210 - 231

15. Dolu O. Suç Teorileri: Teori, Araştırma ve Uygulamada Kriminoloji. 5. Basım. Global Politika ve Strateji Yayınları, 2015;Ankara

16. Polis Vazife Ve Salâhiyet Kanunu, (1934). Resmi Gazete, 14 Temmuz 1934

17. Çoban E. Ülkemizin yeni bilgi ve güvenlik konsepti MOBESE. Polis Bilimleri Dergisi, 2005;45. 21-28. Akt: Kula, S., \& Guler, A. (2016). Smart public safety: Application of mobile electronic system integration (MOBESE) in Istanbul. In Smarter as the New Urban Agenda (pp. 243-258). Springer, Cham.

18. Armitage R. To CCTV or not to CCTV. A review of current research into the effectiveness of CCTV systems in reducing crime. Nacro. 2002;London

19. Karasar N. Bilimsel Araştırma Yöntemi. 15. Baskı. Nobel Yayın Dağıtım, 2005;Ankara.

20. Teevan JJ. Subjective Perception of Deterrence (Continued). Journal of Research in Crime and Delinquency, 1976;13(2), 155-164. DOI: https://doi. org $/ 10.1177 / 002242787601300206$

21. Dolu O, Büker H. Caydırıcılığın Sınırları: Caydırıcılık Eksenli Suç Önleme ve Mücadele Politikalarına Eleştirel bir Yaklaşım. Polis Bilimleri Dergisi, 2009;11(3), 1-22

22. Özcan Y, Dolu O, Gül SK. Ceza Algısının Uyuşturucu Kullanımı Üzerindeki Caydırıcı Etkisi: Bursa İli Ortaöğretim Kurumlarında Yapılan Bir Alan Araştırması. Turkish Journal of Police Studies/Polis Bilimleri Dergisi, 2011;13(4). 
23. Türk B, Yavuz MF. Caydırıcılığın Madde Kullanımı Açısından Üniversite Öğrencilerinde Değerlendirilmesi, Adli Tıp Bülteni; 2018;23(3): 143-150. DOI: https://doi. org/10.17986/blm.2018345588

24. Chambliss WJ. The deterrent influence of punishment. Crime \& Delinquency, 1966;12(1), 70-75.

25. Dumrul AC, Danacı AHK. "Kadın ve Kız Çocuklarına KarŞ1 İşlenen Cinsel Şiddet Suçlarında Cezasızlık Sorunu Raporu. Ankara Barosu Dergisi, 2015;(4):255-291
26. Delice M. Hiz, alkol ve genel trafik denetimlerinin trafik kazaları üzerindeki etkilerinin incelenmesi. Atatürk Üniversitesi Sosyal Bilimler Enstitüsü Dergisi, 2012;16(2).

27. Türkmen M. Ceza Sosyolojisi Açısından Türkiye'de Ceza Adalet Politikaları ve Denetimli Serbestlik. Mediterranean Journal of Humanities 2018;8(1):379 - 397. DOI: https:// doi.org/10.13114/MJH.2018.403 